\title{
Analysing The Relationship Between Job Satisfaction And Life Satisfaction In Terms Of Demographic Variables: An Research in Accommodation Businesses
}

\author{
İrfan YAZICIOĞLU
}

Associate Professor, Gazi University, Faculty of Tourism, Turkey

irfanyaz@gazi.edu.tr

\section{Neslihan KUBİLAY}

Republic of turkey Ministry of Culture and Tourism, Turkey neskubilay@gmail.com

\begin{abstract}
The aim of the study is to determine the correlation between job satisfaction and life satisfaction of employees, also, to reveal this relation's differentiation through demographic variables. The study is carried out through employees who work in 4-5 star hotels in Ankara. The sample size was determined as 384 employees by using Yamane's formula (2001). A questionnaire was used to collect data from sample group. Mann-Whitney U Test, Kruskal-Wallis $\mathrm{H}$ Test and Spearman Correlation Coefficient were used in the analysis of obtained data. According to analysing of collected data, it was ascertained that job satisfaction and life satisfaction influence one another positively. In term of demographic variables, concerning age and gender, life satisfaction differs significantly; whereas job satisfaction does not show much differentiation. Concerning marital status and the experiences in the field, it is confirmed that there is no significantly differentiation for both. Once and for all, the variables of education, monthly income shows a significantly differentiation in the levels of life satisfaction and job satisfaction.
\end{abstract}

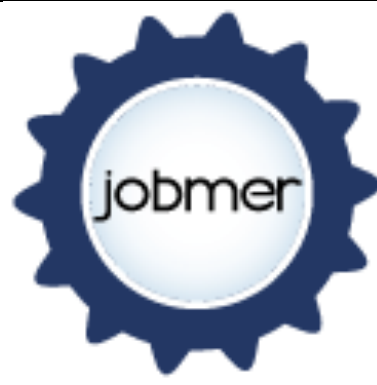

Journal of Business Management and Economic Research Vol.1, Issue.1, 2017 pp.39, 48

Doi: 10.29226/jobmer.2017.3

Key Words: Job satisfaction, Life satisfaction

\section{Suggested Citation:}

Yazıcıoğlu, İ., Kubilay N., (2017) Analysing The Relationship Between Job Satisfaction And Life Satisfaction In Terms Of Demographic Variables: An Research in Accommodation Businesses, Journal of Business Management and Economic Research, Vo.1, Issue.1, pp.39-48 


\section{INTRODUCTION}

Nowadays, human resource is the primary factor for service businesses to gain sustainable competitive advantage over their rivals. Since production in service businesses mostly depend on labor, workers have a considerable effect on the consumer satisfaction regarding the service. All the attraction and beauties might become meaningless in the hands of a bad service. In this regard, psychological states of the workers who are psychological entities become more of an issue. Job satisfactions is one of the key factors that widely affects the behaviors employees display in the business. The more the employees are satisfied, the more motivated thus the happier they become. It is likely that a service provided by a happy employee will satisfy the consumer. In this context, it is vital for both the employer and the employee to determine the relationship between job satisfaction and life satisfaction which is one of the major elements affecting the employee's happiness.

\section{JOB SATISFACTION}

Job satisfaction can be defined as the positive attitudes regarding the work and the state of contentedness which occurs when the employee adapted himself to his work environment (Karcioğlu v.d., 2009:59).

Job satisfaction indicates the employee's physical and mental state regarding the work (Bingöl, 1986: 227). Each individual has different qualities that are unique to themselves. Likewise, job satifaction factors vary from individual to individual and culture to culture.

The factors affecting employees' job satisfaction can be explained under two main headings as individual factors and organizational factors. In the framework of these factors, management should protect both the executives and the employees' benefits. Such act is essential for the welfare of the employees and the executives. The individual factors affecting job satisfaction can be listed as; personality traits, age, gender, marital status, educational status, job, seniority, position and socio-cultural environment. Apart from individual factors, organizational factors such as the workplace and conditions determine job satisfaction. Organizational factors can be listed as; the work itself, wage, work safety, promotion, workplace and conditions, management style, co-workers, organization culture and stress.

Job satisfaction signifies that an employee is content with his job and that he feels peaceful and safe in his workplace, which is crucial for businesses. Cases in which job satisfaction is not obtained results in behavioral disorders. Many disorders such as emotional breakdowns, fatigue(as a result of lack of sleep), loss of appetite and inattentiveness results from job dissatisfaction (Baştemur, 2006: 48).

\section{LIFE SATISFACTION}

The concept of life satisfaction,coined by Neugarten in 1961, is the consequence of the relationship between what the individual expects and what he has. Life satisfaction is obtained when the individual evaluates his/her own life and finds out that he is in a favorable status. (Diener, Emmons, Larsen ve Griffin, 1985). The perception of life satisfaction is stated through the individual's self-assesment of life and subjective judgements of himself/herself (Pavot and Diener, 1993). Life satisfaction derives from one's reactions towards work and leisure times (Sung-Mook and Giannakopoulos, 1994). According to Özdevecioğlu (2003) life satisfaction is the emotional attitudes outside of one's working life. According to Dikmen (1995) life satisfaction is to achieve subjective well-being and the goal of spending quality time in regard to the facts of life.

Once the individual strikes a work-life balance, it is easier for him/her to achieve life satisfaction. Besides, it enables the development of processes such as reaching a highproductivity level, long-term working life, qualified business process, decreasing 
impediments and increasing motivation and commitment, which will lead the business to success. Once some time is allocated for activities such as vacation and sleep -which are the sources of motivation- performance increases accordingly, and it is easier to achieve work-life balance. Factors that affect life satisfaction can be listed under four main headings as individual, occupational, environmental and social factors.

According to Keser (2005) factors that affect life satisfaction are as follows;

- $\quad$ Feeling content in the daliy life

- Determination in achieving goals

- $\quad$ Positive individual identity

- Being physically at peace with oneself

- Well being in terms of economics, safety and social relations

Although there are ongoing debates on the measurability of life satisfaction due to its subjective nature it is known that scales aimed at measuring life satisfaction are developped. Scales developped for life satisfaction often evaluates the individual's emotional and living conditions. Satisfaction with Life Scale developped by Diener, Emmons, Larsen and Griffin (1985) is one of these scales. It is a 7 point likert scale consisting of 5 items that measures the life satisfaction of alla ge groups from adolescents to adults.

\section{THE RELATIONSHIP BETWEEN JOB SATISFACTION AND LIFE SATISFACTION}

Life satisfaction, in general, signifies the combination of the satisfaction achieved in one's working life and social life. As Keser (2005) states, the relationship between the satisfaction regarding working life and the satisfaction of life was first investigated in the works of Brayfield, Wells and Strate in 1957. Aforementioned works put forth the fact that occupational satisfaction affects the indivudal's whole life outside of work in a positive way.

Since the working life has a vital sphere of influence in one's life it is quite normal that it penetrates his/her whole life. Inadequate job satisfaction,thus, the unhappiness, disappointments, and reluctance affects the overall living conditions and decreases the satisfaction one gets from life. By affecting the individual's relations concerning the environment, family and friends in a negative way, this condition results in physcial and mental disorders (Çetinkanat, 2000:48).

Various studies on the relationship between job and life satisfacton are available. (Chacko,1983; Lee, 1991; Ulguç v.d., 1998; Vara, 1999; Özdevecioğlu, 2003; Özdevecioğlu, 2004; Keser 2005; Baştemur, 2006; Braynt et al., 2006; Heler et al., 2006; Hayes and Weathington, 2007; Aşan and Erenler, 2008; Eren, 2008; Mazerolle et al., 2008; Karimi, 2009). In some of these works done in various branches of business a positive relationship between job and life satisfaction is determined. (Chacko,1983; Lee, 1991; Özdevecioğlu, 2004; Keser 2005; Baştemur, 2006; Braynt et al., 2006; Heler et al., 2006; Hayes and Weathington, 2007; Aşan and Erenler, 2008; Eren, 2008; Mazerolle et al., 2008; Karimi, 2009). Whereas in some works no relationship was found between job satisfaction and life satisfaction (Vara, 1999; Şener and Acuner, 2002). Researchers stated that employees who are satisfied with their wages, who recieve psychological support and have the chance to participate in social activities, and who have their own choice of job can achieve higher levels of job and life satisfaction (Eren, 2008). On the other hand, Lee (1991) stated that due to their low wages, inability to work within the scope of their knowledge and skills workers job and life satisfaction decreased. Karimi (2009) whereas stated that job and life satisfaction decreased due to the excessive amounts of overtime. 
In their work investigating the interaction between job burnout and life satisfaction Hayes and Weathington (2007) determined, again in line with the literature, that employees working free from stress have increasingly higher levels of individual success which affects life satisfaction positively.

Current research aimes to put forth the relationship between job satisfaction and life satisfaction of employees working in hospitality establishments which constitute a great part of the tertiary industry, and to determine differentiations with regards to demographic variables (gender, marital status, age, working time, education, monthly income). The datas this research will put forward are thought to be important for executives of hospitality establishments to develop policies and practices to enhance the performances of establishments at the macro level, and employees at the micro level, and to determine tools of motivation.

\section{METHOD}

The aim of this study is to put forth the relationship between the job satisfaction and life satisfaction of hospitality establishment employees and to determine whether it differentiates in terms of demographic variables. Population in this resarch is constitued by approximately 5000 employees who work in 4 and 5 star hotels located in Ankara province (ÇSGB,2015). When determining the sample size the minimum sample determination formula developped by Yamane (2001, p.116-117) is used. In accordance with the formula the minimum is determined as 384 . When choosing the sample group the convenience sampling method is prefered. The prepared survey consists of two sections. In the first section of the survey questions regarding the participants' demographic qualities appear, and in the second section a job satisfaction scale comprised of 20 items and a life satisfaction scale comprised of 5 items appear. Minnesota Job Satisfaction scale developped by Weiss, Dawis England and Lofquist (1967) and Life Satisfaction scale developped by Diener, Emmons, Larsen and Griffin (1985) is used. By using survey form research data is collected from the employees working in 4 and 5 star hotels located in Ankara province. While analyzing the obtained data Mann- Whitney U Test, Kruskal-Wallis H Test, and Spearman's Correlation Coefficient is used. The obtained datas' confidence is analyzed. Cronbach's alpha value for the life satisfaction scale is found as 0,86 whereas Cronbach's alpha value for job satisfaction scale is found as 0,93 . Research model is given in Figure 1.

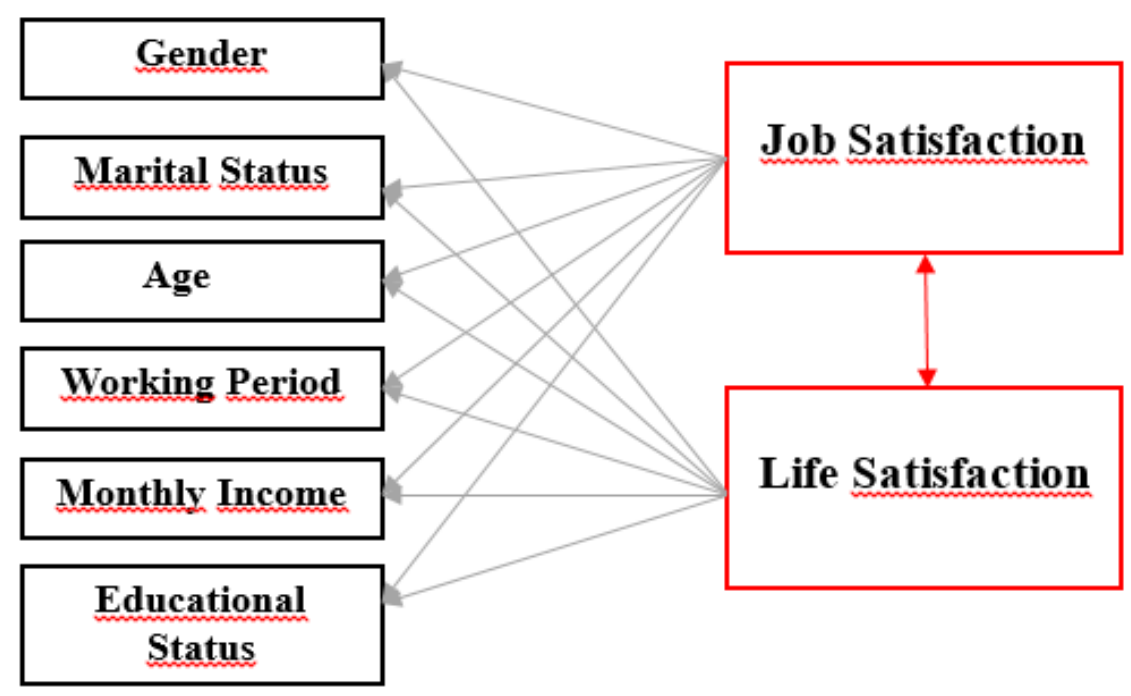

Figure 1. Research Model 


\section{Journal of Business Management and Economic Research}

Hypotheses in accordance with the research model are as follows;

$H_{1}$ :A meaningful relationship exists between the employees' job satisfaction and life satisfaction.

$\mathrm{H}_{2}$ :Employees' job satisfaction significantly differentiates according to the gender variable.

$\mathrm{H}_{3}$ :Employees' life satisfaction significantly differentiates acording to the gender variable

$H_{4}$ :Employees' job satisfaction significantly differentiates according to the marital status variable.

$H_{5}$ :Employees' life satisfaction significantly differentiates according to the marital status variable.

$H_{6}$ :Employees' job satisfaction significantly differentiates according to the age variable.

$H_{7}$ : Employees' life satisfaction significantly differentiates according to the age variable

$\mathrm{H}_{8}$ :Employees job satisfaction significantly differentiates according to the working period variable.

H9: Employees life satisfaction significantly differentiates according to the working period variable..

$H_{10}$ :Employees job satisfaction significantly differentiates according to the monthly income variable.

H11: Employees life satisfaction significantly differentiates according to the monthly income variable.

. $H_{12}$ : Employees job satisfaction significantly differentiates according to the educational status variable.

H13: Employees life satisfaction significantly differentiates according to the educational status variable.

\section{FINDINGS}

Demographic qualities of the participants are given in Table 1.

Table 1. Demographic Qualities of the Participants

\begin{tabular}{|c|c|c|c|c|c|c|c|c|}
\hline Gender & & $n$ & $\%$ & \multicolumn{2}{|c|}{ Marital Status } & $n$ & \multicolumn{2}{|l|}{$\%$} \\
\hline Male & & 263 & 69,2 & \multicolumn{2}{|l|}{ Single } & 160 & \multicolumn{2}{|l|}{41,8} \\
\hline Female & & 117 & 30,8 & \multicolumn{2}{|c|}{ Married } & 223 & \multicolumn{2}{|l|}{58,2} \\
\hline Age & & $n$ & $\begin{array}{c}E \\
S t\end{array}$ & \multicolumn{2}{|c|}{$\begin{array}{l}\text { Educational } \\
\text { Status }\end{array}$} & $N$ & \multicolumn{2}{|l|}{$\%$} \\
\hline $18-25$ years & & 83 & 21,8 & \multicolumn{2}{|c|}{$\begin{array}{l}\text { Primary } \\
\text { Education }\end{array}$} & 45 & \multicolumn{2}{|l|}{11,7} \\
\hline $26-30$ years & & 78 & 20,5 & \multicolumn{2}{|c|}{ Highschool } & 174 & \multicolumn{2}{|l|}{45,3} \\
\hline $31-35$ years & & 95 & 24,9 & \multicolumn{2}{|c|}{$\begin{array}{l}\text { Associate } \\
\text { degree }\end{array}$} & 61 & \multicolumn{2}{|l|}{15,9} \\
\hline $36-40$ years & & 56 & 14,7 & \multicolumn{2}{|c|}{$\begin{array}{l}\text { Bachelor's } \\
\text { Degree or } \\
\text { upper }\end{array}$} & 104 & \multicolumn{2}{|l|}{27,1} \\
\hline \multicolumn{2}{|c|}{41 years and older } & 69 & 18,1 & & & & & \\
\hline Çalışma Süresi & $n$ & $\%$ & Monthly Income & $N$ & $\%$ & Department & $n$ & $\%$ \\
\hline 0-1 year & 45 & 11,7 & 0-1000 TL & 83 & 22,1 & $F \& B$ & 83 & 22,8 \\
\hline $2-5$ years & 112 & 29,2 & $1001-1500 \mathrm{TL}$ & 163 & 43,5 & Front Office & 125 & 34,3 \\
\hline $6-10$ years & 93 & 24,2 & $1501-2000 \mathrm{TL}$ & 77 & 20,5 & Housekeeping & 42 & 11,5 \\
\hline $11-15$ years & 60 & 15,6 & 2001-2500 TL & 23 & 6,1 & Technic & 22 & 6,0 \\
\hline \multirow[t]{2}{*}{$\begin{array}{l}16 \text { years and } \\
\text { more }\end{array}$} & 74 & 19,3 & $\begin{array}{l}2501 \text { TL and } \\
\text { more }\end{array}$ & 29 & 7,7 & Security & 27 & 7,4 \\
\hline & & & & & & Other & 65 & 17,9 \\
\hline
\end{tabular}


As seen in Table 1, males constitue $69,2 \%$ and females constitute $30,8 \%$ of the participants. When the maritial statuses examined married participants constitute $58,2 \%$ and singles constitute $41,8 \%$ of the participants. When the ages are examined the highest rate belongs to participants aged between 31-35 years with $24,9 \%$, whereas the lowest rate belongs to the participants aged between $36-40$ with $14,7 \%$. When educational statuses are examined high school graduates constitues the majority with $45,3 \%$. In terms of working period by a ratio of $29,2 \%$ employes who work for $2-5$ years, in terms of monthly income by a ratio of $43,5 \%$ employees who have 1000-1500 TL income, and in terms of work departments by a ratio of $34,3 \%$ front office workers outnumber.

In Table 2 standard and average deviation values of the answers given to the items in Job Satisfaction Scale appear. According to Table 2 it is seen that highest average belongs to the expressions "In terms of getting along with co-workers" and "in regard to being given the chance of bearing conscientious responsibilty" and the lowest average belongs to the expressions "in terms of the sense of achievement as the result of the work done" and "in terms of the fee for the work done"

Table 2. The Avarege and Standard Deviation Valuse of Job Satisfaction Scale Items

\begin{tabular}{|l|l|c|c|}
\hline & \multicolumn{1}{|c|}{ LIFE SATISFACTION SCALE } & average* & s.d \\
\hline 1 & "In many aspects my life is close to my ideals." & 3,61 & 1,92 \\
\hline 2 & "My life conditions are excellent." & 3,54 & 1,76 \\
\hline 3 & "I am satisfied with my life" & 4,14 & 1,76 \\
\hline 4 & "So far I have got the things I want in life." & 3,82 & 1,83 \\
\hline 5 & $\begin{array}{l}\text { "If I could live again my life, I would change almost nothing." } \\
\text { * Questions asked in 7 point likert style indicate, 1 Strongly disagree, 2 Disagree, 3 } \\
\text { Slightly disagree, 4 Neither agree nor disagree, 5 Slightly agree, 6 Agree, 7 Strongly } \\
\text { agree. }\end{array}$ & 2,00 \\
\hline
\end{tabular}

In the research the relationship between job satisfaction and life satisfaction is examined and in order to put this relationship forth the correlation analysis is given in Table 4.

Table 4. Spearman Correlation Test and Analysis of Job and Life Satisfaction Relationship

\begin{tabular}{|c|c|c|c|c|}
\hline & & & Life Satisfaction & Job Satisfaction \\
\hline \multirow{6}{*}{ Spearman's rho } & \multirow{3}{*}{ Life Satisfaction } & rho & 1,000 &, $591^{*}$ \\
\hline & & $p$ & & ,000 \\
\hline & & $n$ & 384 & 384 \\
\hline & \multirow{3}{*}{ Job Satisfaction } & rho &, $591^{*}$ & 1,000 \\
\hline & & $p$ & ,000 & \\
\hline & & $n$ & 384 & 384 \\
\hline
\end{tabular}

${ }^{*} \mathrm{p}<0,05$ 
According to the correlation analysis given in Table 4 a correlation which is at $5 \%$ level of significance $(p<0,05 r h o=, 591)$, positive, and moderate exists between the level of life satisfaction and the level of job satisfaction. According to this, as the job satisfaction levels of employees increase life satisfaction levels increase, and as their life satisfaction levels increase, their job satisfaction levels increase.

Table 5. Differentiations In The Participants' Job and Life Satisfaction In Regard To Gender and Marital Status Variables

\begin{tabular}{|c|c|c|c|c|}
\hline \multirow{2}{*}{ Gender } & Male $(n=263)$ & Female $(n=117)$ & \multirow{2}{*}{$\mathbf{U}$} & \multirow{2}{*}{ p } \\
\hline & Mean Rank & Mean Rank & & \\
\hline JOB SATISFACTION & 180,86 & 212,17 & 12,850 & 676 \\
\hline LIFE SATISFACTION & 188,93 & 194,03 & 14,972 & ,010 \\
\hline \multirow{2}{*}{ Marital Status } & Single $(n=160)$ & Married(n=223) & \multirow{2}{*}{$\mathbf{U}$} & \multirow{2}{*}{ p } \\
\hline & Mean Rank & Mean Rank & & \\
\hline JOB SATISFACION & 182,09 & 199,11 & 17,474 & 732 \\
\hline LIFE SATISFACTION & 189,71 & 193,64 & 16,254 & 137 \\
\hline
\end{tabular}

According to Table 5 whereas the job satisfaction levels do not differ significantly in terms of gender variable $p>0,05 \mathrm{U}=12,850)$, life satisfaction levels significantly differ $(p<0,05 \mathrm{U}=14,972)$. It is understood that females life satisfaction levels are higher compared to males'. In terms of differentiation with respect to the marital status variable no differentiation is observed. In other words, marital status is not a determining factor in job and life satisfaction.

Table 6. Differentiation in Job and Life Satisfaction of the Participants According to Age and Working Period Variables

\begin{tabular}{|c|c|c|c|c|c|c|c|}
\hline \multirow[t]{2}{*}{ Age } & $\begin{array}{c}18-25 \\
\text { years } \\
(\mathrm{n}=83)\end{array}$ & $\begin{array}{c}26-30 \\
\text { years } \\
(\mathrm{n}=78)\end{array}$ & $\begin{array}{l}31-35 \\
\text { years } \\
(\mathrm{n}=95)\end{array}$ & $\begin{array}{l}36-40 \\
\text { years } \\
(\mathrm{n}=56)\end{array}$ & $\begin{array}{c}41 \text { years } \\
\text { and older } \\
(n=69)\end{array}$ & \multirow[t]{2}{*}{$x^{2}$} & \multirow[t]{2}{*}{$p$} \\
\hline & $\begin{array}{l}\text { Mean } \\
\text { rank }\end{array}$ & $\begin{array}{c}\text { Mean } \\
\text { rank }\end{array}$ & $\begin{array}{c}\text { Mean } \\
\text { rank }\end{array}$ & $\begin{array}{c}\text { Mean } \\
\text { rank }\end{array}$ & $\begin{array}{c}\text { Mean } \\
\text { rank }\end{array}$ & & \\
\hline JOB SATISFACTION & 176,81 & 212,96 & 202,64 & 184,91 & 172,17 & 7733 & 102 \\
\hline $\begin{array}{c}\text { LIFE } \\
\text { SATISFACTION }\end{array}$ & 182,33 & 201,44 & 209,55 & 198,54 & 157,97 & 10402 & ,034 \\
\hline \multirow[t]{2}{*}{ Working Period } & $\begin{array}{c}0-1 \text { year } \\
(n=45)\end{array}$ & $\begin{array}{c}2-5 \text { years } \\
(n=112)\end{array}$ & $\begin{array}{c}6-10 \\
\text { years } \\
(n=93) \\
\end{array}$ & $\begin{array}{c}11-15 \\
\text { years } \\
(n=60)\end{array}$ & $\begin{array}{c}16 \text { years } \\
\text { and more } \\
(n=74)\end{array}$ & \multirow[t]{2}{*}{$x^{2}$} & \multirow[t]{2}{*}{$p$} \\
\hline & $\begin{array}{c}\text { Mean } \\
\text { rank }\end{array}$ & $\begin{array}{c}\text { Mean } \\
\text { rank }\end{array}$ & $\begin{array}{c}\text { Mean } \\
\text { rank }\end{array}$ & $\begin{array}{c}\text { Mean } \\
\text { rank }\end{array}$ & $\begin{array}{c}\text { Mean } \\
\text { rank }\end{array}$ & & \\
\hline JOB SATISFACTION & 188,68 & 170,96 & 213,72 & 204,11 & 191,34 & 8,342 & , 080 \\
\hline $\begin{array}{c}\text { LIFE } \\
\text { SATISFACTION }\end{array}$ & 205,20 & 171,75 & 205,85 & 202,73 & 191,09 & 6,385 & ,172 \\
\hline
\end{tabular}

The results of Kruskal Wallis test done to understand whether the job and life satisfaction of the employees change according to age and working period variables are given in Table 6. According to Table 6 job satisfaction levels of the participants do not differ significantly $(p>0,05 \chi 2=7,733)$ whereas their life satisfaction levels significantly differ $(p<0,05 \chi 2=10,402)$. 
The age group of 26-30 has the highest rank of job satisfaction. On the other hand age group of 31-35 has the highest rank of life satisfaction. When differentiation is considered in terms of working period no significant differentiation is seen in the employees' job and life satisfaction levels (job satisfaction: $p>0,05 \chi 2=6,385$; life satisfaction: $p>0,05 \chi 2=6,385$ ). According to this, it can be said that age variable is not a determining factor for job and life satisfaction.

Table 7. Differentiation of Participants' Job Satisfaction and Life Satisfaction According to Monthly Income and Educational Status Variables

\begin{tabular}{|c|c|c|c|c|c|c|c|}
\hline \multirow[t]{2}{*}{ Monthly Income } & $\begin{array}{c}0-1000 \\
T L \\
(n=83)\end{array}$ & $\begin{array}{c}1001-1500 \\
\text { TL } \\
(n=163)\end{array}$ & $\begin{array}{l}1501-2000 \\
\text { TL }(n=77)\end{array}$ & $\begin{array}{l}2001-2500 \\
\text { TL }(n=23)\end{array}$ & $\begin{array}{c}2501 \mathrm{TL} \\
\text { and more } \\
(\mathrm{n}=29)\end{array}$ & \multirow[t]{2}{*}{$x^{2}$} & \multirow[t]{2}{*}{$p$} \\
\hline & $\begin{array}{c}\text { Mean } \\
\text { rank }\end{array}$ & $\begin{array}{l}\text { Mean } \\
\text { rank }\end{array}$ & $\begin{array}{l}\text { Mean } \\
\text { rank }\end{array}$ & $\begin{array}{l}\text { Mean } \\
\text { rank }\end{array}$ & $\begin{array}{c}\text { Mean } \\
\text { rank }\end{array}$ & & \\
\hline $\begin{array}{c}\text { JOB } \\
\text { SATISFACTION }\end{array}$ & 174,90 & 169,52 & 230,73 & 140,63 & 253,47 & 32,913 & ,000 \\
\hline $\begin{array}{c}\text { LIFE } \\
\text { SSATISFACTION }\end{array}$ & 168,50 & 171,29 & 205,71 & 197,22 & 283,41 & 31,325 & ,000 \\
\hline \multirow[t]{2}{*}{ Educational Status } & \multicolumn{2}{|c|}{$\begin{array}{l}\text { Primary Education } \\
\qquad(\mathrm{n}=45)\end{array}$} & $\begin{array}{l}\text { Highscho } \\
\text { ol }(\mathrm{n}=174)\end{array}$ & $\begin{array}{c}\text { Associate } \\
\text { degree } \\
(n=61)\end{array}$ & $\begin{array}{c}\text { Bachelor }^{\prime} \\
\text { s degre } \\
\text { and } \\
\text { upper } \\
(\mathrm{n}=104)\end{array}$ & \multirow[t]{2}{*}{$x^{2}$} & \multirow[t]{2}{*}{$p$} \\
\hline & \multicolumn{2}{|c|}{ Mean rank } & $\begin{array}{c}\text { Mean } \\
\text { rank }\end{array}$ & $\begin{array}{c}\text { Mean } \\
\text { rank }\end{array}$ & $\begin{array}{c}\text { Mean } \\
\text { rank }\end{array}$ & & \\
\hline $\begin{array}{c}\text { JOB } \\
\text { SATISFACTION }\end{array}$ & \multicolumn{2}{|c|}{136,71} & 167,47 & 235,55 & 233,26 & 43,450 & ,000 \\
\hline $\begin{array}{c}\text { LIFE } \\
\text { SATISFACTION }\end{array}$ & \multicolumn{2}{|c|}{135,90} & 167,67 & 190,30 & 259,83 & 58,836 & ,000 \\
\hline
\end{tabular}

The results of the analysis done to determine the differentiation of job satisfaction and life satisfaction of the employees according to monthly income and educational status variables are given in Table 7. According to Table 7 it is seen that the job and life satisfaction levels of the participants significantly differ according to their income and educational background görülmektedir ( $\mathrm{p}<0,05 \chi 2=32,913, \mathrm{p}<0,05 \chi 2=31,325, \mathrm{p}<0,05 \chi 2=43,450, \mathrm{p}<0,05 \chi 2=58,836)$. The group with 1501-2000 TL income has the highest rate of job satisfaction and life satisfaction. In terms of education variable the highest rate of job satisfaction is seen in associate degree graduates whereas the highest rate of life satisfaction is seen in master's graduates.

\section{CONCLUSION AND DISCUSSION}

According to the resarch results a significant, moderate positive relationshio exists between the participants' job satisfaction and life ssatisfaction levels. As job satisfaction level increases life satisfaction level increases and as life satisfaction level increases job satisfaction level increases. Acording to this the hypothesis $\mathbf{H}_{1}$ is accepted.

While life satisfaction level of females is significantly higher than males', they have a similar level of satisfaction in terms of job satisfaction. When marital statuses are examined no significant differentiation is found in the life and job satisfaction levels of the single and married participants. According these datas while Hypothesis $\mathbf{H}_{3}$ is accepted, Hypotheses $\mathbf{H}_{2}$, $\mathbf{H}_{4}$ and $\mathbf{H}_{5}$ can not be accepted.

While significant differentiations occur in life satisfaction according to age, no significant differentiation is found in the job satisfaction level. While age is a distinctive factor for life 
satisfaction level, it is not a distinctive for job satisfaction level. Age group of 41 and over has the lowest average of life satisfaction; age group of 31-35 has the highest average of life satisfaction. The participants' working periods in the industry do not make significant differentiations in job and life satisfaction. The life and job satisfaction levels of employees of different working periods are similar. As a consequence, hypothesis $\mathbf{H}_{7}$ is accepted while hypotheses $\mathbf{H}_{6}, \mathbf{H}_{8}$ and $\mathbf{H}_{9}$ can not be accepted.

Life satisfaction and job satisfaction levels of the employees of different income groups show significant differentiation. When income-based life satisfaction levels are examined it is determined that as the income increases the level of life satisfaction increases. In the income group of 2001-2500 TL, however, life satisfaction level remains in a lower level compared to the previous level of income. Participants with 0-1000 TL income have the lowest average of life satisfaction; those with 2501TL income and more have the highest average of life satisfaction. When job satisfaction levels are examined it is seen that as income increases the level of job satisfaction increases likewise in life satisfaction level. However, employees of 2001-2500 income group showed a lower level of job satisfaction compared to the preceding level of income. Participants with 2001-2500 TL income have the lowest average of job satisfaction; those with 2501 TL income or more have the highest average of job satisfaction. Based on these datas; hypotheses $\mathbf{H}_{10}$ and $\mathbf{H}_{11}$ are accepted.

Employees with different educational background have different levels of job and life satisfaction. In terms of life satisfaction levels it is determined that as the level of education increases the level of life satisfaction increases. Primary school graduates have the lowest average of life satisfaction; Bachelor's graduates and Master's graduates have the highest average of life satisfaction. Employees with a Associate, Bachelor's and Masters degree have similar levels of job satisfaction. According to these datas hypotheses $\mathbf{H}_{12}$ and $\mathbf{H}_{13}$ are accepted.

Results obtained in the research supports the previously determined relationship between the level of life satsfaction and the level of job satisfaction. Individuals with high levels of job satisfaction have high levels of life satisfaction. Previous researches usually put forth the existence of a relationship between job satisfaction and life satisfaction (Baştemur, 2006; Özdevecioğlu 2003; Chacko,1983; Lee, 1991; Aydıntan and Koç, 2016). Although it is stated that a large number of studies accept the fact that due to role differences gender does not make any sense in terms of life satisfaction (Keser, 2003:199) according to the research conducted by Özdevecioğlu(2003) female employees are observed to have a higher level of life satisfaction compared to male employees. Again in the same research no significant differentiation in life satisfaction is determined in terms of maritial status. This result confirms Özdevecioğlu(2003)'s study.

In Herzberg(1968)'s research on the relationship between the individuals' life satisfaction and age variable it is determined that while life satisfaction is higher at early and old ages, it is lower in middle ages. In the research he conducted on job satisfaction a higher job satisfaction level is observed in young employees which decreases towards the middle ages and increases again in later ages with experience (Aksayan, 1990:15). However Koç et al. (2009:19), Koç and Yazıcıoğlu (2011:54) suggested that job satisfaction does not show a significant differentiation according to age and this result corresponds to the result of the study. Acording to İşcan and Timuroglu (2007)'s study a positive relationship between the working period in industry and job satisfaction is determined. While the relationship between age and job satisfaction is confirmed, it does not show any similarities in its relationship with other variables.

In a research done in England it is observed that employees with a master's degree experienced job dissatisfaction more compared to those with lower educational backgrounds (Baştemur, 2006). Likewise, Koç et al. (2009:154) suggested that job satisfaction in terms of 
education variable does not show a significant differentiation. In the framework of this research resuşts it is seen that contrary to current studies levels of job and life satisfaction increase as the level of education increases.

In a general sense it is known that the relationship between life satisfaction and job satisfaction is positive. Keser (2003) states this as: the higher the individual's income, the higher life satisfaction he/she has and the happier he/she is as long as the income fulfills the demands and expectations. Results confirm this expression as employees with the highest income have a higher life satisfaction compared to the other income groups.

Results of the research show that a positive relationship exists between job satisfaction and life satisfaction and business executives need to take steps to enhance the levels of employees' job satisfaction and life satisfacyion. 